\title{
PERLINDUNGAN HUKUM TERHADAP KEKERASAN PADA ANAK
}

\author{
$\underline{\text { Rianawati }}$ \\ Pusat Studi Gender dan Anak \\ Institut Agama Islam Negeri (IAIN) Pontianak \\ Email: irin_ptk@ymail.com
}

\begin{abstract}
There are many types and causes in a violence behavior. One of the action in the domestic field is the violence performed by parents, family, and the close neighborhood on children. Furthermore, the children abuse violates the buman rights since as a bumankind, children bave the rights even from their birthday. The children assault will dangerously cause the fatal result, physically and psychologically on a child. The violences on children are the act against the laws, UN Declaration about Human Rights and UU RI No. 39 Tabun 1999 verse 53. Besides, Islam probibits the violent acts on children as well.
\end{abstract}

Keywords: Violence, Children, The Causes, Laws, Islamic Beliefs

\section{PENDAHULUAN}

Pelanggaran hak asasi manusia sering terjadi saat ini. Kemajuan ilmu dan teknologi, globalisasi, dan kemajuan industri telah melunturkan nilai-nilai kasih sayang dan penghormatan serta penghargaan seseorang terhadap nilai-nilai etis, etika, moral, dan agama, sehingga seseorang dengan mudah menyakiti orang lain dengan tujuan-tujuan tertentu. Oleh sebab itu, banyak pelanggaran hak asasi terjadi dalam berbagai bentuk, utamanya dalam bentuk kekerasan fisik maupun psikis. Kekerasan dapat terjadi pada siapa saja. Umumnya kekerasan terjadi pada orang-orang yang lemah, seperti anak, perempuan, dan orang tua (lansia).Kekerasan biasanya didominasi orang-orang yang kuat dan berkuasa. Kekerasan dikatakan melanggar hak-hak asasi karena kekerasan merampas hak-hak kebebasan, hak-hak untuk hidup dengan baik dan mendapatkan perlakuan yang baik pula.

Penyebab terjadinya tindak kekerasan sangat bervariasi dan jenisnyapun bervariasi. Salah satu bentuk kekerasan dalam rumah tangga adalah kekerasan yang dilakukan oleh orang tua, keluarga, dan orang-orang di sekitarnya kepada anaknya. Kekerasan pada anak melanggar Hak Asasi Manusia, hal ini karena selaku manusia, anak adalah makhluk Tuhan Yang Maha Esa yang memiliki hak asasi sejak dilahirkan, sehingga tidak ada manusia atau pihak lain yang boleh merampas hak tersebut. Hak asasi anak diakui secara universal sebagaimana tercantum dalam Piagam PBB dan Deklarasi PBB Tahun 1948 tentang Hak Asasi Manusia, Deklarasi ILO, ILO (International Labour Organisation) di Philadelphia tahun 1944, Konstitusi ILO, Deklarasi PBB tahun 1959 tentang Hak Anak, Konvensi PBB Tahun 1966 tentang Hak - hak Ekonomi, Sosial, dan Budaya dan Konvensi PBB Tahun 1989 tentang Hak Anak, Konvensi ILO No. 182 Tahun 1999 tentang pelanggaran dan Tindakan Segenap Penghapusan Bentukbentuk Pekerjaan Terburuk Untuk Anak (disetujui pada Konverensi Ketenagakerjaan Internasional ke - 87 tanggal 17 Juni 1999 di Jenewa). (Koesparmono, Irsan dalam Jean K. Matuankotta, 2011: 70)Dan pasal 53 Undang-undang Republik Indonesia Nomor 39 tahun 1999 pada ayat : 1) Setiap anak sejak dalam kandungan berhak untuk hidup, mempertahankan 
hidup, da meningkatkan kehidupannya. 2) Setiap anak sejak kelahirannya berhak atas suatu nama dan status kewarganegaraan. (Koesparmono, Irsan dalam Jean K. Matuankotta, 2011: 71)

Berdasarkan Deklarasi PBB tentang Hak-hak Asasi Manusia dan UU. Republik Indonesia di atas, dapat disimpulkan bahwa anak memiliki hak hidup, mempertahankan, dan meningkatkan hidupnya, memiliki kebebasan, memiliki kebutuhan yang harus dipenuhi oleh orang tua, keluarganya, dan negara. Oleh sebab itu, tindakan kekerasan terhadap anak, merupakan tindakan yang bertentangan Deklarasai PBB tentang hak asasi manusia dan Undang-undang Republik Indonesia No.39 Tahun 1999 pasal 53.

Tindak kekerasan pada anak di rumah dilakukan oleh orang, keluarga atau orang di sekitar anak. Sebab-sebab tindak kekerasan dilakukan karena ada perilaku anak yang menjengkelkan orang tua, sehingga orang tua mudah memukul fisik anaknya dan mengeluarkan kata-kata verbal yang menyakiti perasaan.. Tindakan kekerasan orang tua pada anak sangat mudah dilakukan bilamana orang tua sedang menghadapi masalah dan kurang dapat mengendalikan emosinya dengan baik. Akibat pemukulan fisik dan psikis pada anak akan berdampak buruk, baik yang berkaitan dengan fisik, berupa luka, memar, pendarahan pada anggota tubuh, penyiksaan, cacat seumur hidup bahkan dapat menyebabkan kematian pada anak. Kekerasan verbal pada anak dapat berupa cacian, ancaman, penghinaan, dan katakata yang menyakitkan perasaan anak. Tindakan kekerasan pada anak tidak saja dilakukan oleh orang tua tetapi orang-orang terdekat lainnya yang berada di sekitar anak. Kakak, abang, kakek, nenek, atau pihak keluarga yang lain. Anak-anak sangat mudah dan rentan mendapatkan kekerasan. Karena pada dasarnya anak-anak sering melakukan kesalahan dan kadang-kadang membuat jengkel orang tua dan keluarganya.

Pada umumnya masyarakat menganggap kekerasan dalam rumah tangga terhadap anak urusan "dapur" satu keluarga. Orang tua juga, tak sedikit, beranggapan bahwa anaknya adalah hak milik dan tanggung jawabnya hingga ia berhak melakukan apa saja, termasuk membantingnya karena kesal menyebabkan anak meninggal atau atas nama mendidik, membina dan melaksanakan tugasnya sebagai orang tua, anak sah-sah saja dihukum, dipukul, dimarahi, dicubit, dijewer hingga disiksa. Anak sejak kecil sudah diajarkan agar patuh dan taat kepada orang tua dengan cara kekerasan. Orang tua dalam menerapkan disiplin kepada anak sering tidak memperhatikan keberadaan anak sebagai seorang manusia. Anak sering dibelenggu aturan-aturan orang tua yang tidak rasional dan tanpa menghargai keberadaan anak dengan segala hak-haknya, seperti hak anak untuk bermain. Hirarki sosial yang diajarkan adalah hirarki otoriter, sewenang-wenang. Tak hanya di desa, tetapi juga di kota hal ini masih banyak terjadi. Tidak pula hanya oleh orang tua yang katanya tak sekolahan, orang tua yang terpandang di masyarakat ternyata juga ada sebagai aligator (pemangsa buas) atau penindas anak di rumah. (Sulaiman Zuhdi Manik, 2011)

Persoalan ekonomi, pertengkaran, dan perceraian orang tua sering menjadi sebab terjadinya tindak kekerasan pada anak. Anak menjadi sasaran kemarahan, kekesalan, dan masalah yang menimpa orang tua. Kekerasan yang terjadi pada anak sulit dilihat seberapa jauh kekerasan yang dilakukan oleh orang tua pada anak. Apakah anak sering menerima kekerasan fisik atau kekerasan verbal atau kedua-duanya.Orang-orang atau masyarakat sekitarnya sulit membedakan mana tindakan yang kekerasan atau mana tindakan yang merupakan bagian dari pendidkan. 
Orangtua yang memiliki temperamen yang tinggi biasanya mendidik anak-anaknya dengan nada yang tinggi pula. Tidak jarang mereka menjewer atau menempeleng anaknya atau bahkan membentak dengan kasar. Anak-anak sedikitpun tidak mempunyai kebebasan dalam berbuat, anak-anak selalu diatur dan melakukan sesuatu menurut kehendak orang tuanya. Anak-anak tidak mempunyai pilihan-pilihan yang mereka sukai. Hidup anak tertekan di rumah orang tua mereka sendiri. Anak-anakpun dipaksa mengerjakan pekerjaan rumah bahkan anakanak juga dipaksa untuk membantu ekonomi keluarga, seperti menjual koran, mengemis, membantu orang tuanya berjualan, dan sebagainya.

Sangat sulit memantau tindakan kekerasan yang dilakukan oleh orang tua. Tindakan hukumanpun sulit menjangkau perilaku keras terhadap anak. Karena tidak ada bukti kekerasan verbal misalnya yang dilakukan oleh orang tua di rumah. Kecuali tindakan kekerasan berat berupa pembunuhan atau tindakan yang menimbulkan cacat pada anak. Tindakan kekerasan berat ini barulah ditindak lanjuti. Padahal, tindakan hukum yang dijatuhkan kepada orang tua yang melakukan kekerasan tidak akan bermanfaat bagi anak yang sudah mengalami cacat atau kematian. Seharusnya kekerasan ringan yang dilakukan oleh orang tua terhadap anak inilah sedini mungkin ditindak lanjuti, sehingga mudah mengantisipasi jangan sampai terjadi kekerasan yang dapat membahayakan psikis anak, anggota badan ataupun nyawa anak.

Berdasarkan ulasan tentang deteksi dini tindak kekerasan yang dilakukan oleh orang tua atau keluarga, maka seharusnya pemerintah telah menyiapkan mekanisme atau perangkat hukum untuk mendeteksi dini kekerasan yang dilakukan di rumah tangga. Mengatasi persoalan kekerasan terhadap anak memang diperlukan berbagai tindakan sekaligus. Di Malaysia, selain undang-undang perlindungan anak dan kekerasan dalam rumah tangga yang telah ada, dengan segera pemerintah kerajaan membuat sebuah sistem deteksi dini, rujukan, penanganan terpadu untuk menanggapi masalah kekerasaan. Di Malaysia sejak awal tahu 90-an telah dibentuk SCAN TEAM ( Suspected Child Abuse and Neglect Team ) yang keberadaannya diakui oleh seluruh jajaran pemerintahan sampai pada tingkat Rumah Tangga dan anggota teamnya terdiri dari relawan masyarakat dan pegawai kerajaan, serta anggota kepolisian dan profesi kesehatan. Setiap kasus ditangani secara terpadu dan semua pemeriksaan, termasuk pemeriksaan kesehatan biayanya ditanggung oleh pemerintah federal. (Irwanto, 2011)

Tulisan ini akan membahas tentang bentuk-bentuk kekerasan, dampak fisik, psikis, dan sosial serta perlindungan anak, baik menurut pandangan Islam maupun menurut Undangundang Perlindungan Anak, khususnya Undang-undang RI nomor 23 Tahun 2002 tentang Perlindungan Anak.

\section{DEFENISI KEKERASAN ANAK}

Kekerasan adalah semua bentuk perilaku verbal non ferbal yang dilakukan oleh seseorang terhadap orang lain sehingga menyebabkan efek negatif secara fisik maupun psikologis pada orang yang menjadi sasarannya. (Erfaniah Zuhriah, dalam Susanto, 2006: 13) Kekerasan adalah suatu tindakan yang dilakukan oleh seseorang atau sejumlah orang yang berposisi kuat (atau yang tengah merasa kuat) terhadap seseorang atau sejumlah orang yang berposisi lebih lemah (atau dipandang berada didalam keadaan lebih lemah), bersaranakan kekuatannya-entah fisik maupun non fisik yang superior dengan kesengajaan untuk dapat 
ditimbulkan rasa derita dipihak yang tengah obyek kekerasan. (Mufidah dalam Susanto, 2006: 13)

Berdasarkan pengertian beberapa pengertian di atas, kekerasan adalah suatu tindakan yang dilakukan oleh seseorang (orang yang berkuasa) yang dapat menimbulkan sakit, penderitaan, baik fisik, psikis, dan sosial pada seseorang (identik orang yang lemah).

Sedangkan pengertian kekerasan terhadap anak adalah (child abuse) adalah semua bentuk perlakuan menyakitkan secara fisik ataupun emosional, penyalahgunaan seksual, pelalaian, eksploitasi komersial atau eksploitasi lain, yang mengakibatkan cedera/kerugian nyata ataupun potensial terhadap kesehatan anak, kelangsungan hidup anak, tumbuh kembang anak, atau martabat anak, yang dilakukan dalam konteks hubungan tanggung jawab, kepercayaan, atau kekuasaan. (Faqih dalam Daisy Widiastuti dan Rini Sekartini, 2005: 106)

Secara teoritis, kekerasan terhadap anak (child abuse) didefinisikan sebagai perlakuan fisik, mental, atau seksual yang umumnya dilakukan oleh orang-orang yang mempunyai tanggung jawab terhadap kesejahteraan anak yang mana semua diindikasikan dengan kerugian dan ancaman terhadap kesehatan dan kesejahteraan anak. Contoh paling jelas dari tindak kekerasan yang dialami anak-anak adalah pemukulan atau penyerangan secara fisik berkali-kali sampai terjadi luka atau goresan. Namun demikian perlu disadari bahwa child abusesebetulnya tidak hanya berupa pemukulan atau penyerangan fisik saja, melainkan juga berupa berbagai eksploitasi melalui pornografi dan penyerangan seksual, (sexual assault) pemberian makanan yang tidak layak bagi anak atau makanan kurang gizi (malnutrition), pengabaian pendidikan dan kesehatan yang berkaitan dengan medis (medical abuse)(Bagong Suyanto dan Sri Sanituti, 2002:114)

Kekerasan terhadap anak, menurut Soeroso (dalam Ratna Dewi Anggraini, 2013: 2) bahwa kekerasan terhadap anak adalah setiap perbuatan yang ditujukan pada anak yang berakibat kesengsaraan dan penderitaan baik fisik maupun psikis baik yang terjadi di depan umum atau dalam kehidupan pribadi. Tindak kekerasan tidak hanya berupa tindakan fisik melainkan juga perbuatan non fisik (psikis). Tindakan fisik secara langsung bisa dirasakan akibatnya oleh korban serta dapat dilihat oleh siapa saja, sedangkan tindakan non fisik (psikis) yang bisa merasakan langsung hanyalah korban, karena tindakan tersebut langsung berkaitan yang menyinggung hati nurani atau perasaan seseorang.

Kekerasan pada anak adalah kekerasan yang obyeknya adalah anak sebagai sasaran perilaku kekejaman sesorang yang menimbulkan sakit dan penderitaan pada fisik, psikis, maupun sosial anak, bahkan dapat menimbulkan cacat atau bahkan dapat menghilangkan nyawa anak. Kekerasan pada anak biasanya dilakukan oleh orang tua, keluarga, tetangga sekitar rumah, atau orang tua asuh anak. Kekerasan pada anak biasanya dalam bentuk kata-kata kasar, pemukulan, eksploitasi tenaga anak untuk bekerja, penelantaran, dan kekerasan dalam bentuk seksual.

Kekerasan merujuk pada tindakan agresi dan pelanggaran (penyiksaan, pemerkosaan, pemukulan, dan lain-lain) yang menyebabkan atau dimaksudkan untuk menyebabkan penderitaan atau menyakiti orang lain. Istilah kekerasan juga berkonotasi kencederungan agresif untuk melakukan perilaku yang merusak. Kekerasan terjadi ketika seseorang menggunakan kekuatan, kekuasaan, dan posisinya untuk menyakiti orang lain dengan sengaja, bukan karena kebetulan, kekerasan juga meliputi ancaman, dan tindakan yang bisa mengakibatkan luka dan kerugian. Luka yang diakibatkan bisa berupa luka fisik, perasaan, 
pikiran, yang merugikan kesehatan dan mental. Kekerasan anak adalah segala bentuk tindakan yang melukai dan merugikan fisik, mental, dan seksual termasuk hinaan meliputi, penelantaran dan perlakuan buruk, eksploitasi termasuk eksploitasi seksual, serta trafficking jual beli anak. Sedangkan Child Abuseadalah semua bentuk kekerasan terhadap anak yang dilakukan oleh mereka yang seharusnya bertanggung jawab atas anak tersebut atau mereka yang memiliki kuasa atas anak tersebut, yang seharusnya dapat dipercaya, misalnya orang tua, keluarga dekat, dan guru.

\section{BENTUK KEKERASAN ANAK}

Menurut, Haidar Nasir, (1997: 58), bentuk kekerasan apapun bentuknya, mulai dari penelantaran, eksploitasi, diskriminasi sampai pada perlakuan yang tidak manusiawi, akan terekam dalam alam bawah sadar mereka hingga beranjak dewasa bahkan sepanjang hidupnya. Tindakan-tindakan tersebut dapat dikategorikan sebagai child abuse atau perlakuan kejam terhadap anka-anak. Terry E. Lawson, (dalam Lyle E. Bourne, JR., 2001: 115) membagi child abuse menjadi 4 macam, yaitu emotional abuse, terjadi ketika orang tua mengetahui anaknya membutuhkan perhatian, mereka justru mengabaikannya. Ibu membiarkan anak basah atau lapar karena ibu terlalu sibuk atau tidak ingin diganggu pada waktu itu. Ibu boleh jadi mengabaikan kebutuhan anak untuk dipeluk atau dilindungi. Anak akan mengungat semua kekerasan emosional jika kekerasan tersebut berlangsung konsisten. Verbal abuse terjadi ketika ibu mengetahui anaknya meminta perhatian, menyuruh anak itu untuk "diam" atau "jangan menangis". Jika anak mulai bicara, ibu terus menerus menggunakan kekerasan verbal seperti, "bodoh", " cerewet", "kurang ajar", dan lain sejenisnya. Physical abuse, ketika ibu memukul anak (ketika sebenarnya anak membutuhkan perhatian) memukul anak dengan tangan, kayu, kulit, logam, atau benda-benda keras lainnya akan diingat oleh anak. Sexual abuse, biasanya tidak terjadi selama delapan belas bulan pertama dalam kehidupan anak. Walaupun beberapa kasus ketika anak perempuan menderita kekerasan seksual dalam usia enam belas bulan pertama.

Bentuk kekerasan pada anak sebagaimana dalam pembahasan di atas, menjelaskan bahwa bentuk kekerasan pada anak berupa kekerasan emosi, kekerasan dengan kata-kata, kekerasan pada tubuh anak, dan kekerasan seksual. Kekerasan emosi yaitu penolakan dari orang-orang yang dekat secara emosional dengan anak untuk memberikan perhatian, cinta, dan kasih sayang pada anak, sehingga membuat perasaan anak tidak bahagia, sedih, tertekan, dendam, benci, dan tidak suka pada orang tersebut. Kekerasan verbal atau kekerasan dengan kata-kata yaitu seseorang yang mempunyai hubungan dekat dengan anak mengeluarkan katakata kasar atau kata yang tidak disenangi, menyakitkan, atau kata-kata yang mengecewakan perasaan anak, sehingga anak kecewa dan sedih serta mencurahkan kesedihannya dengan tangisan, atau kemarahan dan dendam di hatinya.

Selanjutnya bentuk kekerasan lainnya adalah kekerasan fisik atau kekerasan yang ditujukan pada tubuh anak, sehingga dapat melukai atau membuat cacat atau bahkan dapat menghilangkan nyawa anak. Kekerasan pada anak bersifat fisik ini dilakukan dengan pemukulan dengan bantuan alat, penamparan pipi, mencubit, melukai anak dengan alat-alat berbahaya, merendam dan menyiram anak dengan air dan cara-cara berbahaya lainnya yang dilakukan secara sengaja oleh seseorang yang mempunyai hubungan dekat dengan anak. 
Biasanya kekerasan yang dilakukan disebabkan karena ketidaksabaran seseorang terhadap perilaku anak, anak dijadikan sasaran kemarahan, tekanan kondisi ekonomi dan sosial.

Lebih lanjut wujud kekerasan sebagaimana yang dijelaskan oleh Syamsul Bachri Thalib (2010: 191) bahwa kekerasan psikis terdiri dari tiga kategori yaitu kekerasan psikologis, kekerasan verbal, dan kekerasan simbolik. Kekerasan psikologis seperti sikap mengingkari persamaan hak dan kemanusiaan. Selanjutnya yaitu kekerasan verbal berupa ucapan yang merendahkan diri atau penghinaan. Bentuk yang ketiga yang termasuk kekerasan psikis yaitu kekerasan simbolik yaitu tindakan yang menimbulkan rasa takut dan permusuhan.

Kekerasan psikologis sebagaimana pernyataan Syamsul Bahri adalah kekerasan yang dilakukan dalam bentuk kekerasan psikis, yaitu melakukan ketidakadilan terhadap seseorang, (menginjak hak dan martabat dan membedakan perlakuannya itu dari orang yang lain) mengindahkan hak-hak yang harusnya diterimanya, (mengabaikan hak-hak yang seharusnya diterima), melakukan tindakan yang tidak manusiawi, (memperlakukan anak yang tidak sesuai dengan sifat-sifat kemanusiaan, sehingga terkesan anak diperlakukan seperti binatang).

Sedangkan kekerasan verbal menurut pandangan Syamsul Bahcri adalah kekerasan yang dilakukan dengan kata-kata dimana seseorang melakukan tindakan kekerasan dengan mencela, menghina, memperolok, memanggil dengan kata-kata yang melukai perasaan anak, bahkan mempersamakan anak dengan binatang, Selanjutnya kekerasan simbolik adalah kekerasan dengan intimidasi atau ancaman sehingga menimbulkan rasa kekhawatiran, gelisah, kesedihan, dendam dan benci, takut, dan bahkan rasa permusuhan.

Sebenarnya ke-3 jenis kekerasan sebagaimana yang dimaksud oleh Syamsul Bachri di atas, digolongkan sebagai kekerasan fisik. Kekerasan jenis ini tidak begitu mudah dikenali. Akibat yang dirasakan korban tidak memberikan bekas yang nampak jelas bagi orang lain.Dampak kekerasan jenis akan berpengaruh pada situasi perasaan tidak aman dan nyaman, menurunkan harga dirinya serta martabat korban. Wujud konkrit kekerasan jenis ini adalah penggunaan kata-kata kasar, penyalahgunaan kepercayaan, mempermalukan orang lain di depan orang lain, melaontarkan ancaman dengan kata-kata dan sebagainya. Akibat adanya perilaku tersebut biasanya korban akan rendah diri, minder, merasa tidak berharga, dan lemah dalam membuat keputusan. (Bagong Suyanto, 2010: 28)

Menurut Suharto (dalam Abu Huraerah, 2012: 48) bahwa kekerasan anak secara psikis, meliputi penghardikkan, penyampaian kata-kata kasar dan kotor, memperlihatkan buku, gambar, film pornografi terhadap anak. Anak yang mendapatkan perlakuan ini umumnya menunjukkan gejala perilaku maladatif, seperti menarik diri, pemalu, menangis jika didekati, takut ke luar rumah dan takut bertemu dengan orang lain. Selain itu menurut Suharto, kekerasan non fisik tidak saja mengarah pada kekerasan verbal, namun lebih daripada itu memperlihatkan film kekerasan pada anakpun termasuk kekerasan psikis, menterornya dengan hal-hal yang menakutkan juga termasuk dengan kekerasan psikis yang apabila anak secara terus menerus mendapatkan tekanan seperti ini, maka mental anak akan tumbuh dan berkembang secara tidak wajar. Dan kemungkinan remaja dan dewasanya akan mempunyai pribadi yang aneh.

Lebih lanjut, kekerasan anak lebih bersifat sebagai bentuk penganiayaan fisik dengan terdapatnya tanda atau luka pada tubuh anak. Jika kekerasan terhadap anak di dalam rumah tangga dilakukan orang tua, maka hal tersebut dapat disebut kekerasan dalam rumah tangga. Tindak kekerasan rumah tangga yang termasuk didalam tindakan kekerasan rumah tangga 
adalah memberikan penderitaan yang baik secara fisik maupun mental diluar batas-batas tertentu terhadap orang yang berada didalam satu rumah, seperti terhadap pasangan hidup, anak, atau orang tua dan tindak kekerasan tersebut dilakukan di dalam rumah. (Kadnet, 2010)Penganiayaan fisik adalah tindakan-tindakan kasar yang mencelakakan anak, dan segala bentuk kekerasan fisik pada anak yang lainnya.

Akibat kekerasan fisik yang dapat melukai badan anak, apabila dilakukan membabi buta akan berakibat fatal pada anak, misalnya cacat tubuh menetap atau bahkan dapat mengakibatkan kematian pada anak. Oleh karena itu, tidak dianjurkan bahkan dilarang keras bagi setiap orang tua yang akan memberikan hukuman fisik kepada anak. Hal-hal di atas akan terjadi pada anak, bila dilakukan tanpa kendali.

\section{DAMPAK KEKERASAN ANAK}

Kekerasan akan menimbulkan berbagai dampak negatif pada anak. Dampak yang ditimbulkan pada fisik, psikis, dan moral. Sebagaimana hasil penelitian yang dilakukan oleh Ratna Dewi Anggraini (2013: 3-4) sebagai berikut :

1. Dampak kekerasan fisik, yaitu dampak kekerasan yang dialami oleh anak, dimana dampak yang dirasakan oleh anak bisa berupa sakit secara fisik yaitu luka-luka, benjolan di tubuhnya, dan memar.Dampak yang terjadi dapat secara langsung maupun tidak langsung atau dampak jangka pendek dan dampak jangka panjang. Pertumbuhan dan perkembangan anak yang mengalami kekerasan pada umumnya lebih lambat pada anak yang normal, yaitu:

a. Dampak langsung terhadap kejadian child abuse 5\% mengalami kematian, 25\% mengalami komplikasi serius seperti patah tulang, luka bakar, cacat menetap.

b. Terjadi kerusakan menetap pada susunan syaraf yang dapat mengakibatkan retardasi mental, masalah belajar/kesulitan belajar, buta, tuli, masalah dalam perkembangan motor/pergerakan kasar dan halus, kejadian kejang, ataksia, ataupun hidoscfalus.

c. Pertumbuhan fisik anak pada umumnya kurang dari anak-anak sebayanya, tetapi Oates dkk. pada tahun 1984 mengatakan bahwa tidak ada perbedaan yang bermakna dalam tinggi badan dan berat badan dengan anak normal. (Daisy Widiatuti dan Rini Sekatini, 2005: 110-111)

Kekerasan fisik pada anak sangat berdampak tidak baik pada fisik anak. Seperti luka pada beberapa bagian tubuh anak, atau pada sekujur tubuh anak yang akan menimbulkan rasa sakit dan penderitaan. Bila kekerasan mengenai kepala anak yang merupakan pusat syaraf atas atau mengenai bagian belakang tubuh anak bawah punggung adalah pusat syaraf bawah, maka bisa dipastikan akan terjadi kerusakan syaraf atas atau bawah, sehingga anak akan mengalami cacat tetap, misalnya kebutaan, bisu, tuli, kesulitan memusatkan perhatian, anggota badan seperti tangan bergerak sendiri tanpa kendali, anak menjadi idiot dan sulit berpikir serius atau berpikir sederhana, pelupa, menurunnya kecerdasan anak, atau kelumpuhan.

2. Dampak kekerasan psikis, yaitu anak menarik diri dari lingkup rumah tangganya dan katakata kasar yang selalu diterimanya itu menjadi kebiasaan sendiri untuk berbicara seperti ini. Perkembangan kejiwaan juga mengalami gangguan, yaitu: 
a. Kecerdasan, berbagai penelitian melaporkan bahwa terdapat keterlambatan dalam perkembangan kognitif, bahasa, membaca, dan motorik. Retardasi mental dapat diakibatkan trauma langsung pada kepala, juga karena malnutrisi. Anak juga kurang mendapat stimulasi adekuat karena gangguan emosi.

b. Emosi, masalah yang sering dijumpai adalah gangguan emosi. Kesulitan belajar/sekolah, kesulitan dalam mengadakan hubungan dengan teman, kehilangan kepercayaan diri, fobia, cemas. Beberapa anak menjadi ageresif atau bermusuhan dengan orang dewasa, atau menarik diri/menjauhi pergaulan. Anak suka mengompol, hyperaktif, perilaku aneh, kesulitan belajar, gagal sekolah, sulit tidur, temper tantrum.

c. Konsep diri, anak yang mendapat kejadian cbild abusemerasa dirinya jelek, tidak dicintai, tidak dikehendaki, muram dan tidak bahagia, tidak mampu menyenangi aktifitas, dan melakukan percobaan bunih diri.

d. Agresif, anak yang mendapat kejadian child abuse lebih agresif tersebut meniru tindakan orang tua mereka atau mengalihkan perasaan agresif kepada teman sebayanya sebagai hasil kurangnya konsep diri.

e. Hubungan sosial, pada anak-anak tersebut kurang dapat bergaul dengan teman sebaya atau dengan orang dewasa, misalnya melempari batu, perbuatan kriminal lainnya.

f. Akibat dari sexual abuse, tanda akibat trauma atau infeksi lokal, seperti nyeri perineal, sekret vagina, nyeri dan perdarahan anus, tanda gangguan emosi, misalnya konsentrasi kurang, enuresis, enkopresis, anoreksia dan perubahan tingkah laku, kurang percaya diri, sering menyakiti diri sendiri, dan sering mencoba bunuh diri, tingkah laku atau pengetahuan seksual anak yang tidak sesuai dengan umumnya. (Daisy Widiatuti dan Rini Sekatini, 2005: 111)

Dampak kekerasan psikis sebagai ulasan di atas, sangat berakibat fatal bagi pertumbuhan dan perkembangan mental anak. Anak yang didera kekerasan psikis secara terus menerus akan tumbuh suatu kepribadian yang tidak wajar. Utamanya anak tidak dapat bersosialisasi dengan baik dengan orang lain, memandang orang lain penuh kecurigaan, dan memiliki sifat pendendam kepada siapa saja yang mempnyai kemiripan dengan orang yang pernah melakukan kekerasan pada dirinya. Anak seperti ini sangat mudah membahayakan orang lain dan terperangkap pada lingkungan yang tidak baik atau lingkungan rusak sekelilingnya. Dia akan mudah menyakiti orang lain atau bahkan sangat mudah melukai dan membunuh orang lain.

Kekerasan psikis nampaknya merupakan hal yang sepele, khususnya bagi orangtua. Kadang-kadang orangtua tanpa sadar atau sengaja mengeluarkan kata-kata kotor pada anaknya, namun orangtua tidak pernah berpikir, bahwa akibat yang ditimbulkan dari kekerasan psikis sesungguhnya akan menimbulkan dampak negatif, yang bahayanya tidak saja akan membahayakan bagi anaknya sendiri namun juga akan dapat membahayakan orang lain.

3. Dampak kekerasan yang bersifat sosial yaitu akibat dari penelantaran yang dilakukan oleh orangtua adalah anak harus melakukan mengerjakan tugas yang dilakukan oleh ayahnya dan pendidikannya yang bermasalah.

Pada umumnya orangtua yang mempunyai ekonomi kelas menengah ke bawah sering tanpa sadar telah menelantarkan hak-hak anaknya. Hak-hak anak untuk memperoleh makanan dan minum yang sehat dan cukup, pendidikan yang layak bagi 
anak, pakaian dan kebutuhan sandang anak lainnya juga tercukupi, pemberian waktu bermain, istirahat, belajar, dan kebersamaan yang cukup pula bagi anak. Sebaliknya,fenomena yang terjadi pada anak adalah anak dipaksa dan dieksploitasi untuk bekerja, bahkan ada orangtua yang tega menjual anaknya kepada orang lain (untuk diadopsi, dijadikan wanita penghibur, dikawinkan pada usia dini atau pembantu rumah tangga). Keadaan ini seperti sangat mengkhawatirkan bagi tumbuhkembang anak untuk mendapatkan masa depan yang baik dan penuh harapan baginya.

Penelantaran hak-hak anak adalah merupakan kekerasan sosial pada anak. Dalam usia yang tidak layak anak harus bekerja membanting tulang, yang tidak saja dapat merugikan fisiknya namun juga secara psikis anak. Secara fisik, tubuh anak yang belum berkembang sempurna, tinggi dan berat badan yang belum berkembang optimal, tulangnya yang masih kecil dan belum mampu mengangkat beban yang berat, pikirannya juga belum dewasa untuk menerima pekerjaan yang seharusnya dilakukan oleh orang dewasa. Hal ini tentu saja dapat mempengaruhi tumbuh kembang fisik anak, yang kemungkinan bisa saja karena sering menerima dan memikul beban berat, tubuh anak berkembang tidak sempurna. Selain itu, anak yang seharusnya belajar untuk mempersiapkan masa depan yang gemilang, pada akhirnya tidak mempunyai kesempatan belajar apalagi untuk bermain dan bersosialisasi bersama teman-temannya. Banyak waktu anak-anaknya akan terkorbankan karena penelantaran yang dilakukan oleh orangtua.

\section{PERLINDUNGAN ANAK MENURUT UNDANG-UNDANG}

Pada tanggal 26 Januari 1990 di New York, Pemerintah Republik Indonesia telah menandatangani Convention On The Right Of The Child sebagai hasil sidang Majelis Umum PBB yang diterima pada tanggal 20 Nopember 1989, yang kemudian disahkan melalui Keputusan Presiden Republik Indonesia No. 36 Tahun 1990. Dengan telah disahkannya konvensi tersebut maka pemerintah terikat untuk melaksanakan secara penuhhak-hak yang tertuang dalam konvensi tersebut, yang berkaitan dengan masalah :Perlindungan terhadap anak dari kekejaman, penyalahgunaan, penelantaran dan eksploitasi, peran serta anak dalam masyarakat, berpartisipasi dalam kehidupan bermasyarakat sesuai alam pikirnya serta penyediaan segala kebutuhan dasar anak. (Jean K. Matuankotta, 2011:71)

Berkaitan dengan pemenuhan hak anak maka telah dibuat berbagai peraturan perundang-undangan penunjang yakni: Undang-undang Republik Indonesia Nomor 4 Tahun 1979 yang mengatur tentang Kesejahteraan Anak, Undang-undang Republik Indonesia Nomor 3 Tahun 1997 yang mengatur tentang Pengadilan Anak, Undang-undang Republik Indonesia Nomor 39 Tahun 1999 tentang Hak Asasi Manusia(khusus pada pasal 52 sampai dengan pasal 66 yang mengatur tentang hak anak).Adapun setiap anak berhak untuk memperoleh perlindungan bilamana diperlukan, namun juga harus diberikan kesempatan yang lebih besar untuk berpartisipasi dalam hal yang berkaitan dengan tanggungg jawab orang yang lebih tua menyangkut kehidupannya. Pasal 52 Undang-undang Republik Indonesia Nomor 39 tahun 1999 menyebutkan dalam ayat: 1) Setiap anak berhak atas perlindungan oleh orang tua, keluarga, masyarakat dan Negara. 2) Hak anak adalah hak asasi manusia dan untuk kepentingannya hak anak itu diakui dan dilindungi oleh hukum bahkan sejak dalam 
kandungan. Dan pasal 53 Undang-undang Republik Indonesia Nomor 39 tahun 1999 pada ayat:

1. Setiap anak sejak dalam kandungan berhak untuk hidup, mempertahankan hidup, dan meningkatkan kehidupannya.

2. Setiap anak sejak kelahirannya berhak atas suatu nama dan status kewarganegaraan.

Mengacu pada kedua pasal ini makaadalah kewajiban Pemerintah, Negara, Orangtua, dan masyarakat untuk tidak menelantarkan dan wajib peduli terhadap hak anak tersebut. (Jean K. Matuankotta, 2011:71) Adapun yang menjadi persoalan adalah bagaimana nasib anak anak yang dikategorikan sebagai anak - anak terlantar atau ditelantarkan, anak yang berada dalam asuhan keluarga yang tidak mampu (miskin) atau dalam lembaga pengasuhan anak. Pada umumnya anak-anak dengan kondisi demikian sangat rentan dengan persoalan kejelasan status hukumnya yang berkaitan dengan identitas ( nama, tanggal lahir, asal usul, kewarganegaraan ) yang dibuktikan lewat kepemilikan dokumen akta kelahiran. (Dirjen Adminduk, dalam Jean K. Matuankotta, 2011:71).

Selanjutnya rumusan Undang-undang RI nomor 23 tahun 2002 tentang Perlindungan Anak Pasal 1, menyebutkan tentang anak, perlindungan anak, anak terlantar, anak cacat, anak unggul, anak angkat, anak asuh, kuasa asuh, kewajiban orang tua, keluarga, wali, hak anak, masyarakat, pendamping, orang, perlindungan khusus, dan pemerintah, sebagai berikut:

1. Anak adalah seseorang yang belum berusia 18 (delapan belas) tahun, termasuk anak yang masih dalam kandungan.

2. Perlindungan anak adalah segala kegiatan untuk menjamin dan melindungi anak dan hakhaknya agar dapat hidup, tumbuh, berkembang, dan berpartisipasi, secara optimal sesuai dengan harkat dan martabat kemanusiaan, serta mendapat perlindungan dari kekerasan dan diskriminasi.

3. Keluarga adalah unit terkecil dalam masyarakat yang terdiri dari suami istri, atau suami istri dan anaknya, atau ayah dan anaknya, atau ibu dan anaknya, atau keluarga sedarah dalam garis lurus ke atas atau ke bawah sampai dengan derajat ketiga.

4. Orangtua adalah ayah dan/atau ibu kandung, atau ayah dan/atau ibu tiri, atau ayah dan/atau ibu angkat.

5. Wali adalah orang atau badan yang dalam kenyataannya menjalankan kekuasaan asuh sebagai orang tua terhadap anak.

6. Anak terlantar adalah anak yang tidak terpenuhi kebutuhannya secara wajar, baik fisik, mental, spiritual, maupun sosial.

7. Anak yang menyandang cacat adalah anak yang mengalami hambatan fisik dan/atau mental sehingga mengganggu pertumbuhan dan perkembangannya secara wajar.

8. Anak yang memiliki keunggulan adalah anak yang mempunyai kecerdasan luar biasa, atau memiliki potensi dan/atau bakat istimewa.

9. Anak angkat adalah anak yang haknya dialihkan dari lingkungan kekuasaan keluarga orangtua, wali yang sah, atau orang lain yang bertanggung jawab atas perawatan, pendidikan, dan membesarkan anak tersebut, ke dalam lingkungan keluarga orangtua angkatnya berdasarkan putusan atau penetapan pengadilan.

10. Anak asuh adalah anak yang diasuh oleh seseorang atau lembaga, untuk diberikan bimbingan, pemeliharaan, perawatan, pendidikan, dan kesehatan, karena orangtuanya atau salah satu orang tuanya tidak mampu menjamin tumbuh kembang anak secara wajar. 
11. Kuasa asuh adalah kekuasaan orangtua untuk mengasuh, mendidik, memelihara, membina, melindungi, dan menumbuhkembangkan anak sesuai dengan agama yang dianutnya dan kemampuan, bakat, serta minatnya.

12. Hak anak adalah bagian dari hak asasi manusia yang wajib dijamin, dilindungi, dan dipenuhi oleh orangtua, keluarga, masyarakat, pemerintah, dan negara.

13. Masyarakat adalah perseorangan, keluarga, kelompok, dan organisasi sosial dan/atau organisasi kemasyarakatan.

14. Pendamping adalah pekerja sosial yang mempunyai kompetensi profesional dalam bidangnya.

15. Perlindungan khusus adalah perlindungan yang diberikan kepada anak dalam situasi darurat, anak yang berhadapan dengan hukum, anak dari kelompok minoritas dan terisolasi, anak yang dieksploitasi secara ekonomi dan/atau seksual, anak yang diperdagangkan, anak yang menjadi korban penyalahgunaan narkotika, alkohol, psikotropika, dan zat adiktif lainnya (napza), anak korban penculikan, penjualan, perdagangan, anak korban kekerasan baik fisik dan/atau mental, anak yang menyandang cacat, dan anak korban perlakuan salah dan penelantaran.

16. Setiap orang adalah orang perseorangan atau korporasi.

17. Pemerintah adalah Pemerintah yang meliputi Pemerintah Pusat dan Pemerintah Daerah.

Berdasarkan rumusan Undang-undang RI nomor 23 tahun 2002 tentang Perlindungan Anak Pasal 1 di atas, bahwa anak adalah seseorang yang belum berusia 18 tahun, dari sejak kandungan sampai berusia 18 tahun. Anak berhak mendapat pengasuhan, pemeliharaan, dipenuhi hak-haknya sebagai anak dengan layak, baik dari segi kesehatannya, pendidikannya, sandang dan pangannya, mental, emosi, agamanya dengan baik, serta harus mendapatkan perlindungan, baik dari orang tuanya, wali, orang tua angkat, atau keluarganya, bahkan pemerintah. Undang-undang Anak sangat diperlukan untuk menjamin kehidupan anak yang aman, nyaman, damai, dan terpenuhi segala hak-haknya serta terhindar dari segala bentuk kekerasan dan penganiayaan.

Undang-undang RI nomor 23 tahun 2002 pasal 3 menyebutkan tentang tujuan Perlindungan Anak, yaitu sebagai berikut:

"Perlindungan anak bertujuan untuk menjamin terpenuhinya hak-hak anak agar dapat hidup, tumbuh, berkembang, dan berpartisipasi secara optimal sesuai dengan harkat dan martabat kemanusiaan, serta mendapat perlindungan dari kekerasan dan diskriminasi, demi terwujudnya anak Indonesia yang berkualitas, berakhlak mulia, dan sejahtera”.

Berdasarkan rumusan Undang-undang RI nomor 23 tahun 2002 pasal 3 di atas maka anak-anak harus mendapatkan perlindungan dalam semua haknya agar anak dapat hidup dengan baik, tumbuh dan berkembang secara wajar, baik fisik maupun psikisnya, sehingga anak kelak dapat berpartisipasi secara optimal sesuai dengan kemampuan fitrah anak. Hak-hak anak harus ditumbuh kembangkan sesuai dengan harkat dan martabat kemanusiaan agar terwujud anak Indonesia yang berkualitas, berakhlak mulia, dan sejahtera. Anak-anak harus tumbuh dan berkembang secara alami dan tidak ada diskriminasi dan ketidakadilan yang dapat menghambat tumbuh kembang anak secara wajar.

Undang-undang RI nomor 23 tahun 2002 pasal 7 ayat 1 tentang hak anak terhadap orangtua, yaitu sebagai berikut: 
"(1) Setiap anak berhak untuk mengetahui orangtuanya, dibesarkan, dan diasuh oleh orang tuanya sendiri(2) Dalam hal karena suatu sebab orangtuanya tidak dapat menjamin tumbuh kembang anak, atau anak dalam keadaan terlantar maka anak tersebut berhak diasuh atau diangkat sebagai anak asuh atau anak angkat oleh orang lain sesuai dengan ketentuan peraturan perundang-undangan yang berlaku".

Berdasarkan rumusan undang-undang RI nomor 23 tahun 2002 pasal 7 ayat 1 di atas dijelaskan bahwa setiap anak berhak diasuh, dirawat, mendapat penghidupan yang layak, dan pendidikan dari orangtuanya dengan kasih sayang yang optimal sampai anak usia dewasa dan dapat mandiri. Bila orangtua tidak mampu memenuhi hak-hak anak dengan optimal, maka orangtua dianjurkan untuk menyerahkan hak pengasuhan, pemeliharaan, dan pendidikan dari orangtua angkat atau wali anak, sehingga diharapkan anak akan dapat tumbuh dan berkembang dengan baik dan dapat berpartisipasi dalam pembangunan bangsa dan negara.

Undang-undang RI nomor 23 tahun 2002 pasal 8 tentang hak anak untuk mendapatkan kesehatan dan jaminan sosial yaitu sebagai berikut: "Setiap anak berhak memperoleh pelayanan kesehatan dan jaminan sosial sesuai dengan kebutuhan fisik, mental, spiritual, dan sosial".

Berdasarkan rumusan undang-undang RI nomor 23 tahun 2002 pasal 8 di atas dapat dijelaskan bahwa anak-anak berhak dan diwajibkan dipenuhi hak-haknya untuk mendapatkan pelayanan kesehatan, dipenuhi gizi dan nutrisinya sesuai dengan tumbuh kembang fisiknya, mendapat perawatan ketika sakit, mendapat tempat tinggal dan lingkungan yang sehat dan layak sesuai dengan standar kesehatan. Anak juga harus mendapatkan jaminan sosial baik untuk fisik, mental, dan sosialnya.

Undang-undang RI nomor 23 tahun 2002 pasal 9 ayat 1 dan 2 tentang hak anak untuk mendapatkan pendidikan yaitu sebagai berikut:

“(1) Setiap anak berhak memperoleh pendidikan dan pengajaran dalam rangka pengembangan pribadinya dan tingkat kecerdasannya sesuai dengan minat dan bakatnya. (2) Selain hak anak sebagaimana dimaksud dalam ayat (1), khusus bagi anak yang menyandang cacat juga berhak memperoleh pendidikan luar biasa, sedangkan bagi anak yang memiliki keunggulan juga berhak mendapatkan pendidikan khusus".

Berdasarkan undang-undang RI nomor 23 tahun 2002 pasal 9 ayat 1 dan 2 di atas dinyatakan bahwa setiap anak tanpa ada perbedaan memperoleh pendidikan dan pengajaran untuk mengembangkan seluruh potensi yang dimiliki sehingga dapat tumbuh dan berkembang secara optimal dan anak kelak diharapkan dapat mengaplikasikan seluruh potensi dan pendidikan yang dimilikinya untuk berkarya dan memperoleh masa depan yang mandiri serta gemilang. Pada undang-undang di atas juga menjelaskan bahwa anak-anak cacat juga berhak memperoleh pendidikan dan menjadi kewajiban bagi orang tua untuk menitipkan pendidikan anaknya di sekolah luar biasa, sehingga anak dapat hidup mandiri dengan kemampuan yang dimilikinya. Anak yang cerdas dan unggul juga harus diberikan kesempatan dengan pendidikan khusus agar potensi unggul yang dimilikinya dapat berkembang secara optimal.

Undang-undang RI nomor 23 tahun 2002 pasal 10 tentang hak anak untuk menyatakan pendapat yaitu sebagai berikut: "Setiap anak berhak menyatakan dan didengar pendapatnya, menerima, mencari, dan memberikan informasi sesuai dengan tingkat kecerdasan dan usianya demi pengembangan dirinya sesuai dengan nilai-nilai kesusilaan dan kepatutan". 
Berdasarkan rumusan undang-undang RI nomor 23 tahun 2002 pasal 10 di atas dapat dijelaskan bahwa setiap anak memiliki kebebasan dan kemerdekaan dalam melakukan inisiatif, kreatif, dan inovatif dalam rangka mempersiapkan anak-anak menjadi manusia yang memiliki kecerdasan intelektual, emosional, dan spiritual. Anak-anak diberi kebebasan untuk memperoleh, mencari, menemukan, dan menyampaikan informasi. Anak-anakpun diberi kebebasan untuk mengolah, mengembangkan, dan mengaplikasikan idenya dalam pelajaran atau dalam kehidupan sehari-hari. Dan anak-anakpun diberi kebebasan untuk menyatakan pendapat, dihargai, diberi masukan, atau diterima pendapatnya untuk mendorong kecerdasan intelektual dan emosional anak.

Undang-undang RI nomor 23 tahun 2002 pasal 11 tentang hak anak untuk beristirahat dan bermain yaitu sebagai berikut: "Setiap anak berhak untuk beristirahat dan memanfaatkan waktu luang, bergaul dengan anak yang sebaya, bermain, berekreasi, dan berkreasi sesuai dengan minat, bakat, dan tingkat kecerdasannya demi pengembangan diri”.

Berdasarkan rumusan Undang-undang RI nomor 23 tahun 2002 pasal 11, dijelaskan bahwa anak-anak berhak beristirahat dengan cukup untuk mendukung kondisi kesehatannya, tumbuh kembangnya, dan sebagai waktu untuk mengistirahatkan seluruh anggota badannya agar dapat stabil kembali untuk melakukan berbagai aktivitas berikutnya. Anak-anakpun harus diberi kebebasan untuk bermain sebagai suatu sarana bagi anak-anak untuk mengembangkan kecerdasannya, untuk memperoleh kegembiraan, mengendorkan syarafnya setelah letih belajar, dan sebagai sarana rekreasi bagi anak. Pergaulan dan kebersamaan dalam mengekspresikan kegembiraan bersama anak-anak sebaya lainnya merupakan kebutuhan utama bagi anak. Membatasi pergaulannya bersama anak-anak yang lain, akan membuat anak bersedih dan tertekan sehingga dapat mempengaruhi tumbuh kembang mental anak. Anak-anakpun harus diberi kebebasan dalam memanfaatkan waktu luang melalui bimbingan dan arahan dari orang tua sehingga penggunaan waktu luang dapat memberi manfaat bagi anak.

Undang-undang RI nomor 23 tahun 2002 pasal 12 tentang hak anak penyandang cacat yaitu sebagai berikut: 'Setiap anak yang menyandang cacat berhak memperoleh rehabilitasi, bantuan sosial, dan pemeliharaan taraf kesejahteraan sosial”.

Berdasarkan rumusan Undang-undang RI nomor 23 tahun 2002 pasal 12 di atas dinyatakan bahwa anak-anak penyandang cacat berhak untuk mendapatkan pemeliharaan kesehatan dan mengoptimalkan fungsi tubuhnya. Bahkan anak-anak cacatpun berhak mendapatkan alat-alat yang dapat menunjang melakukan berbagai aktivitas, seperti kursi roda, tongkat, kaki palsu, alat pendengar, dan lain-lain. Anak-anak cacatpun berhak mendapatkan bantuan sosial, biaya pemeliharaan kesehatan, dan biaya kesejahteraan hidupnya.

Undang-undang RI nomor 23 tahun 2002 pasal 13 tentang hak anak untuk mendapatkan perlindungan yaitu sebagai berikut:

“(1) Setiap anak selama dalam pengasuhan orangtua, wali, atau pihak lain mana pun yang bertanggung jawab atas pengasuhan, berhak mendapat perlindungan dari perlakuan: a. diskriminasi; b. eksploitasi, baik ekonomi maupun seksual; c. penelantaran; d. kekejaman, kekerasan, dan penganiayaan; e. ketidakadilan; dan f. perlakuan salah lainnya. (2) Dalam hal Orangtua, wali atau pengasuh anak melakukan segala bentuk perlakuan sebagaimana dimaksud dalam ayat (1), maka pelaku dikenakan pemberatan hukuman".

Berdasarkan rumusan undang-undang RI nomor 23 tahun 2002 pasal 13 dijelaskan bahwa Orangtua, wali, Orangtua angkat, atau pengasuh anak di lembaga sosial harus 